\title{
Implmentasi Permenkumham Nomor 17 Tahun 2018 Tentang Pendaftaran Persekutuan Komanditer, Persekutuan Firma Dan Persekutuan Perdata Di Kota Yogyakarta
}

\section{Hidayatus Sholehah}

Program Magister Kenotariatan Fakultas Hukum Universitas Islam Indonesia Yogyakarta Indonesia Jln. Cik Di Tiro No. 1 Yogyakarta Indonesia hidayatussholehah08@gmail.com

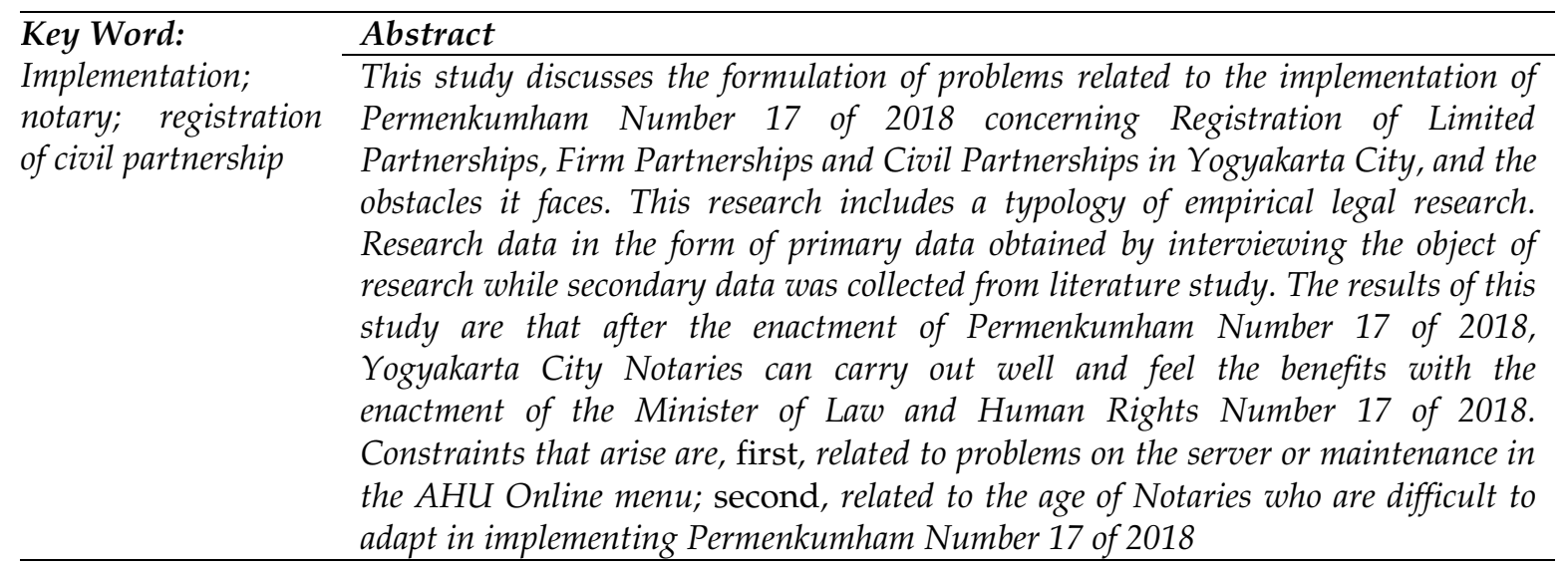

\begin{tabular}{ll}
\hline Kata-kata Kunci: & Abstrak \\
\cline { 2 - 2 } & Penelitian ini memaparkan rumusan masalah terkait implementasi \\
notaris; & Permenkumham Nomor 17 Tahun 2018 tentang Pendaftaran Persekutuan \\
pendaftaran & Komanditer, Persekutuan Firma dan Persekutuan Perdata di Kota \\
persekutuan & Yogyakarta, dan kendala yang dihadapinya. Penelitian ini termasuk tipologi \\
perdata & penelitian hukum empiris. Data penelitian berupa data primer didapat \\
& dengan cara wawancara dengan objek penelitian sedangkan data sekunder \\
& dikumpulkan dari studi pustaka. Hasil dari penelitian ini adalah bahwa \\
& pasca berlakunya Permenkumham Nomor 17 tahun 2018, Notaris Kota \\
& Yogyakarta dapat melaksanakan dengan baik dan merasakan manfaat \\
& dengan berlakunya Permenkumham Nomor 17 Tahun 2018 tersebut. \\
& Kendala yang muncul, pertama, terkait permasalahan di server atau \\
& perawatan dalam menu AHU Online; kedua, terkait usia Notaris yang sulit \\
& beradaptasi dalam menerapkan Permenkumham Nomor 17 Tahun 2018.
\end{tabular}

\section{Pendahuluan}

Mayoritas Industri besar di Indonesia sudah berbentuk badan usaha, sementara itu untuk Usaha Mikro Kecil dan Menengah masih banyak yang belum berbentuk badan usaha. Badan usaha adalah kesatuan yuridis, teknis, dan ekonomis yang bertujuan mencari laba atau keuntungan. Badan usaha disebut sebagai kesatuan yuridis karena biasanya badan usaha tersebut berbentuk badan hukum, sedangkan disebut ekonomis karena faktor-faktor produksi badan usaha terdiri atas sumber daya alam, modal, dan tenaga kerja dikombnasikan untuk mndapat laba dan memberi layanan kepada masyarakat.

Dalam pendrian suatu perusahan wajib didftarkan dalam daftar perusahaan, dan perusahaan yang wajib didaftarkan adalah setiap perusahaan yang berkedudukan di 
wilayah Negara Kesatuan Republik Indonesia menurut ketentuan perundang-undangan yang berlaku sehingga memiliki kewenangan mengadakan suatu perjanjian. ${ }^{1}$

Jika dibandingkan, keuntungan menjalankan usaha dengan mengunakan bentuk badan usaha, lebih banyak dibandingkan dengan yang tidak berbentuk badan usaha. Kitab Undang-Undang Hukum Perdata (KUHPerdata) dan Kitab Undang-Undang Hukum Dagang (KUHD), tidak memberi ketentuan yang mensyaratkan bahwa ketiga bentuk badan usaha itu harus mendaftarkan diri terlebih dahulu agar bisa menjalankan kegiatan usahanya.

Sebelum diterbitkan Permenkumham Nomor 17 Tahun 2018, pendaftaran Persekutuan Komanditer, Persekutuan Firma dan Persekutuan Perdata diregister di kepaniteraan Pengadilan Negeri tempat badan usaha tersebut didirikan, kemudian sejak 1 Agustus 2018 mulai berlaku Permenkumham Nomor 17 Tahun 2018, yang mensyaratkan bahwa pendaftaran Persekutuan Kmanditer, Persekutuan Firma dan Persekutuan Perdata harus dilakukan melalui Sistem Administrasi Badan Usaha (SABU) pada Direktorat Administrasi Hukum Umum (AHU). Penerapan pendaftaran Persekutuan Komanditer, Persekutuan Firma dan Persekutuan Perdata online ini mengadopsi sistem pendaftaran online Perseroan Terbatas (PT) yang sudah berlangsung sebelumnya dan berlaku hingga saat ini.

Keberadaan Notaris makin dibutuhkan dalam rangka membuat suatu alat bukti tertulis yang bersifat otentik dari suatu perbuatan hukum yang dilakukan masyarakat. Beberapa peraturan perundangan mewajibkan perbuatan hukum tertentu dibuat dalam akta otentik. Notaris dan produk akta yang dibuatnya dapat dikatakan sebagai upaya negara untuk menciptakan kepastian dan perlindungan hukum bagi anggota masyarakat. ${ }^{2}$

Suatu perusahaan ketika ingin melakukan pendirian, maka plaku usaha tersebut harus membuat akta pendirian terlebih dahulu yang dilkukan oleh Notris. Berdasarkan Pasal 1 angka 7 Undang- Undang Republik Indonesia Nomor 2 Tahun 2014 tentang Perubahan Atas Undang-Undang Nomor 30 Tahun 2004 tentang Jabatan Notaris, bahwa akta Notaris adalah akta otentik yang dibuat oleh atau dihadapan Notaris menurut bentuk dan tata cara yang di tetapkan dalam Undang-Undang ini. ${ }^{3}$

Adanya aturan baru tersebut juga memberikan dampak pada Persekutuan Komanditer, Persekutuan Firma dan Persekutuan Perdata yang lebih dulu eksis sebelum disahkannya Permenkumham Nomor 17 Tahun 2018. Persekutuan Komanditer, Persekutuan Firma dan Persekutuan Perdata tetap harus mendaftarkan kembali legalitas Badan Usahanya melalui SABU.

Tenggang waktu yang diberikan adalah selama 1 tahun, hanya saja memang tak ada sanksi bagi para Persekutuan Komanditer, Persekutuan Firma dan Persekutuan Perdata yang tidak melakukan pendaftaran atau terlambat mendaftar, hal tersebut dikembalikan lagi kepada Badan Usaha yang bersangkutan, karena pendaftaran ini berkaitan dengan kredibilitas Persekutuan Komanditer, Persekutuan Firma dan

\footnotetext{
${ }^{1}$ Handri Raharjo, Hukum Perusahaan, Pustaka Yustisia, Yogyakarta, 2009, hlm. 13.

2 Hartanti Sulihandari dan Nisya Rifiani, Prinsip-Prinsip Dasar Profesi Notaris Berdasarkan Peraturan PerundangUndangan Terbaru, Cetakan Pertama, Dunia Cerdas, Jakarta, 2013, hlm. 2-3.

${ }^{3}$ Undang-Undang Republik Indonesia Nomor 02 Tahun 2014 tentang Perubahan Atas Undang-Undang Nomor 30 Tahun 2004 tentang Jabatan Notaris
} 
Hidayatus Sholehah. Implementasi Permenkumham No. 17 Tahun 2018... 167

Persekutuan Perdata itu sendiri. Dampaknya jika mereka tidak mendaftarkan, nama Persekutuan Komanditer, Persekutuan Firma dan Persekutuan Perdata bisa saja dipakai oleh orang lain, sehingga badan usaha itu sendiri juga yang akan merugi.

Permenkuham Nomor 17 Tahun 2018 yang mengatur bahwa pendaftaran Persekutuan Komanditer, Persekutuan Firma dan Persekutuan Perdata melalui SABU ini masih relatif baru dan terdapat perbedaan proses pendaftaran dengan sebelum berlakunya Permenkumham Nomor 17 Tahun 2018 sehingga masih ditemukan beberapa notars yang belum mengetahui aturan dan mekanisme pendaftaran tersebut.

Merujuk pada persoalan terkait disahkannya Permenkumham Nomor 17 Tahun 2018 dimana pemahaman Notaris sangat diperlukan, ditambah dengan penggunaan internet pada era digital ini sudah cukup meluas, maka Notaris khususnya di Kota Yogyakarta dapat dikatakan menjadi salah satu acuan apakah dapat menerapkan permenkumham Nomor 17 Tahun 2018 tentang Pendaftaran Persekutuan Komanditer, Persekutuan Firma dan Persekutuan Perdata.

Berdasarkan hal-hal yang telah diuraikan diatas peneliti bermaksud ingin mengetahui Implementasi Permenkuham Nomor 17 Tahun 2018 tentang Pendaftaran Persekutuan Komanditer, Persekutuan Firma dan Persekutuan Perdata di Kota Yogyakarta.

\section{Rumusan Masalah}

Rumusan masalah dari penelitian ini yaitu pertama, bagaimanakah implementasi Permenkumham Nomor 17 Tahun 2018 tentang Pendaftaran Persekutuan Komanditer, Persekutuan Firma dan Persekutuan Perdata di Kota Yogyakarta. Kedua, bagaimana penyelesaian atas kendala yang dihadapi para Notaris tersebut?

\section{Tujuan Penelitian}

Adapun tujuan dari penelitian ini yaitu pertama, untuk mengetahui implementasi Permenkumham Nomor 17 Tahun 2018 tentang Pendaftaran Persekutuan Komanditer, Persekutuan Firma dan Persekutuan Perdata di Kota Yogyakarta. Kedua, penyelesaian atas kendala yang dihadapi para Notaris tersebut.

\section{Metode Penelitian}

Penelitian ini termasuk ke dalam penelitian hukum empiris dengan pendekatan peraturan perundang-undangan, historis, dan konseptual. Penelitian ini adalah penelitian terhadap hukum positif yang terkait dengan implementasi Permenkumham Nomor 17 Tahun 2018.

Data yang digunakan sebagai bahan dalam penelitian ini adalah data primer yang berupa informasi dari 5 Notaris di kota Yogyakarta yang telah melakukan praktek lebih dari 5 tahun, data sekunder, yaitu data yang diperoleh dari bahan pustaka dan terdiri atas penjelasan terhadap data primer yang berasal dari berbagai literatur. Adapun dalam penelitian ini, bahan hukum yang digunakan ialah bahan hukum primer, sekunder, dan tersier. 
Teknik pengumpulan atau pengolahan data yang digunakan oleh penulis untuk data primer melalui wawancara dengan narasumber. Responden yang di jadikan penulis untuk mendapatkan data pendukung yaitu 5 Notaris di kota Yogyakarta yang telah melakukan praktek lebih dari 5 tahun. Terhadap data sekunder, pengumpulan data dilakukan dengan studi kepustakaan. Proses pengumpulan data yang digunakan dalam penelitian ini dilakukan dengan cara membaca, menelaah buku-buku, mempelajari, mencatat dan mengutip buku-buku, peraturan perundang-undangan yang berkaitan dengan permasalahan yang akan di bahas dalam penulisan tesis ini.

Analisis yang digunakan dalam penelitian ini adalah deskriptif kualitatif, yaitu dengan menjabarkan, menguraikan, dan menyusun secara sistematis sesuai dengan tujuan penelitian atau memaparkan keadaan obyek sebagaimana adanya, berdasarkan fakta-fakta aktual yang terjadi sekarang.

\section{Hasil Penelitian dan Pembahasan}

\section{Implementasi Permenkumham Nomor 17 Tahun 2018 tentang Pendaftaran Persekutuan Komanditer, Persekutuan Firmal dan Persekutuan Perdata di Kota Yogyakarta}

Pemerintah dalam hal ini negara mengeluarkan suatu kebijakan berupa Peraturan Pemerintah 24 Tahun 2018 tentang Pelayanan Perizinan Berusaha Terintegrasi Secara Elektronik (OSS), di mana peraturan pemerintah tersebut dikeluarkan dalam rangka percepatan dan peningkatan penanaman modal dan berusaha, serta perlu meningkatkan pelayanan perizinan berusaha terintegrasi secara elektronik. ${ }^{4}$

Online Single Submission (OSS) sendiri merupakan suatu lembaga pengelola dan penyelenggara pemerintah non kementerian yang menyelenggarakan urusan pemerintahan di bidang koordinasi penanaman modal. ${ }^{5}$ Untuk melaksanakan ketentuan Pasal 15 ayat (3), Pasal 16 ayat (3), dan Pasal 17 ayat (3) Peraturan Pemerintah Nomor 24 Tahun 2018 tentang Pelayanan Perizinan Berusaha Terintegrasi Secara Elektronik, perlu menetapkan Peraturan Menteri Hukum dan Hak Asasi Manusia tentang Pendaftaran, Persekutuan Komanditer, Persekutan Firma, dan Persekutuan Perdata yang kemudian terbit Permenkumham Nomor 17 Tahun 2018 tentang Pendaftaran Persekutuan Komanditer, Persekutuan Firma dan Persekutuan Perdata.

Seorang notaris dihadapkan dengan perkembangan ilmu pengetahuan dan teknologi sehingga diharapkan mampu menjalankan kompetensi sesuai kode etik notaris. Dalam kode etik tersebut dijelaskan bahwa seorang notaris diwajibkan meningkatkan ilmu pengetahuan yang telah dimiliki tidak terbatas pada ilmu pengetahuan hukum dan kenotariatan, menyadari ilmu selalu berkembang, dan hukum tumbuh dan berkembang bersama dengan perkembangan masyarakat. ${ }^{6}$

\footnotetext{
${ }^{4}$ Lihat Konsiderensi Huruf (a) Peraturan Pemerintah Republik Indonesia Nomor 24 Tahun 2018 tentang Pelayanan Perizinan Berusaha Terintegrasi secara Elektronik

5 Lihat Pasal 1 angka 11 Peraturan Pemerintah Republik Indonesia Nomor 24 Tahun 2018 tentang Pelayanan Perizinan Berusaha Terintegrasi secara Elektronik

${ }^{6}$ Lihat Pasal 3 kode etik notaris
} 
Kompetensi notaris yang berkaitan dengan pelaksanaan Permenkumham Nomor 17 Tahun 2018 diantaranya melakukan Pendaftaran Persekutuan Komanditer, Persekutuan Firma dan Persekutuan Perdata yang meliputi pendaftaran akta pendirian, pendaftaran perubahan anggaran dasar dan pendaftaran pembubaran.

Kewenangan Notaris jika merujuk pada Permenkumham Nomor 17 Tahun 2018 adalah karena sistem saat ini sudah online, jika terkait pendirian maka harus pesan nama, dan yang bisa melakukan adalah yang memiliki password yaitu Notaris, setelah mendapatkan voucher pesan nama, maka kemudian dibuatkanlah aktanya, dan diinput oleh Notaris, lalu kemudian keluarlah SK.7

Merilee S. Grindle menyebutkan bahwa keberhasilan implementasi dipengaruhi oleh dua variabel besar, yakni isi kebijakan dan lingkungan implementasi. Keberhasilan implementasi suatu kebijakan publik dapat diukur dari proses pencapaian hasil akhir (outcomes), yaitu tercapai atau tidaknya tujuan yang ingin diraih. Hal ini dikemukakan oleh Grindle, dimana pengukuran keberhasilan implementasi kebijakan tersebut dapat dilihat dari 2 hal, yakni:

a. Dilihat dari prosesnya, dengan mempertanyakan apakah pelaksanaan kebijakan sesuai dengan yang ditentukan (design) dengan merujuk pada aksi kebijakannya.

b. Apakah tujuan kebijakan tercapai. Hal ini diukur dengan melihat dua faktor, yaitu:

1) Dampak atau efeknya pada masyarakat secara individu dan kelompok

Dampak implementasi Permenkumham Nomor 17 Tahun 2018 adalah pendaftaran Persekutuan Komanditer, Persekutuan Firma, dan Persekutuan Perdata dilakukan melalui Sistem Administrasi Badan Usaha (SABU) yang dikelola oleh AHU kementerian Hukum dan Hak Asasi Manusia (Administrasi Hukum Umum) yang terintegrasi dengan Online Single Submission (OSS), Notaris kota Yogyakarta dapat menerapkan dengan baik dan merasakan manfaat dengan berlakunya Permenkumham Nomor 17 Tahun 2018 tersebut, dikarenakan prosedur pendaftaran dirasa lebih mudah, efektif, dan efisien, selain itu terkait nama badan usaha yang ada di Indonesia terdata dengan baik didalam sistem, karena ketika pemohon ingin mendaftarkan badan usahanya, maka harus di periksa terlebih dahulu apakah nama badan usaha yang ingin digunakan belum terpakai, dan hal ini memberikan dampak positif karena tidak akan ada kesamaan nama suatu badan usaha di Indonesia.

2) Tingkat perubahan yang terjadi serta penerimaan kelompok sasaran dan perubahan yang terjadi

Notaris di Kota Yogyakarta mendukung diterbitkannya Permenkumham Nomor 17 Tahun 2018 ini karena harus menyesuaikan dengan perkembangan zaman dan sangat bermanfaat pada masa pandemi ini karena segala hal yang berkaitan dengan administrasi diharuskan dengan sistem online, dimana proses pendaftaran lebih cepat, dan biaya yang dikeluarkan tetap sama. Selain itu proses adaptasi oleh Notaris Kota Yogyakarta dalam melaksanakan Permenkumham Nomor 17 Tahun 2018 ini tidak membutuhkan waktu yang lama. ${ }^{8}$

${ }^{7}$ Wawancara dengan Notaris Ika Santy Yurista Bertempat di Yogyakarta, pada 18 September 2020 , pukul 14.23 Waktu Indonesia Bagian Barat

8 Wawancara dengan Notaris Muchammad Agus Hanafi Bertempat di Yogyakarta, pada 18 September 2020, pukul 14.23 Waktu Indonesia Bagian Barat 


\section{Kendala yang Dihadapi Notaris di Kota Yogyakarta dalam Mengimplementasikan Permenkumham No. 17 Tahun 2018 tentang Pendaftaran Persekutuan Komanditer, Persekutuan Firma dan Persekutuan Perdata}

Notaris adalah pejabat umum yang satu-satunya berwenang untuk membuat akta otentik mengenai semua perbuatan, perjanjian dan penetapan yang diharuskan oleh suatu peraturan umum atau oleh yang berkepentingan dikehendaki untuk dinyatakan dalam suatu akta otentik, menjamin kepastian tanggalnya, menyimpan aktanya dan memberikan grosse, salinan dan kutipannya, semuanya sepanjang pembuatan akta itu oleh suatu peraturan umum tidak juga ditugaskan atau dikecualikan kepada pejabat atau orang lain. ${ }^{9}$

Undang-Undang Nomor 30 Tahun 2004 tentang Jabatan Notaris, mengatur bahwa kedudukan Notaris sebagai Pejabat Umum berwenang untuk membuat akta otentik mengenai semua perbuatan, perjanjian dan penetapan yang diharuskan oleh suatu peraturan umum. Pasal 1 Undang-Undang tersebut menyatakan bahwa Notaris adalah pejabat umum yang berwenang untuk membuat akta otentik dan kewenangan lainnya sebagaimana dimaksud dalam Undang-undang ini. Wewenang tersebut meliputi empat hal yaitu: ${ }^{10}$

a. Notaris harus berwenang sepanjang menyangkut akta yang harus dibuat itu. Wewenang notaris dalam pembuatan akta otentik sepanjang tidak dikecualikan kepada pihak atau pejabat lainnya mengandung makna bahwa wewenang tersebut bersifat umum sedangkan pihak lain mempunyai wewenang terbatas. Wewenang ini merupakan suatu batasan bahwa notaris tidak boleh melakukan suatu tindakan diluar wewenag tersebut. Tindakan notaris diluar wewenang yang sudah ditentukan tersebut dikatagorikan sebagai perbuatan melanggar hukum jika menimbulkan permasalahan bagi para pihak, baik secara materiil maupun imatriil dapat diajukan gugatan ke pengadilan.

b. Notaris harus berwenang sepanjang mengenai orang untuk kepentingan siapa akta itu dibuat. Meskipun notaris dapat membuat akta untuk setiap orang tetapi ada batasan tertentu menurut Pasal 52 UUJN, Notaris tidak diperkenankan membuat akta untuk diri sendiri, istri/suami, atau orang lain yang mempunyai hubungan keluarga dengan notaris, baik karena perkawinan atau hubungan darah dalam garis keturunan lurus ke bawah dan atau keatas tanpa pembatasan derajat, serta dalam garis ke samping sampai derajat ke tiga, dan menjadi pihak untuk diri sendiri ataupun dalam suatu kedudukan atau dengan perantaraan kuasa.

c. Notaris harus berwenang sepanjang mengenai tempat, di mana akta itu dibuat Pasal 18 ayat (1) UUJN menentukan bahwa notaris mempunyai tempat kedudukan di daerah kabupaten atau kota. Sedangkan wilayah jabatan notaris meliputi seluruh wilayah propinsi dari tempat kedudukannya Pasal 18 ayat (2), Pengertian dari pasal-pasal tersebut bahwa dalam menjalankan jabatannya notaris tidak harus berada ditempat kedudukannya dikabupaten atau kota tetapi di seluruh wilayah propinsi.

d. Notaris harus berwenang sepanjang mengenai waktu pembuatan akta itu. Dalam hal ini notaris harus menjamin kepastian waktu para penghadap yang tercantum

${ }_{9}$ Habib Adjie, Hukum Notaris Indonesia, Tafsir Tematik Terbadap UU No. 30 Tabun 2004 Tentang Jabatan Notaris, Refika Aditama, Bandung, 2008, hlm. 13 35.

${ }^{10}$ Habib Adjie, Meneropong Khazanah Notaris dan PPAT Indonesia, Citra Aditya Bakti, Bandung, 2009, hlm. 
Hidayatus Sholehah. Implementasi Permenkumham No. 17 Tahun 2018... 171

dalam akta, dan dalam pembuatan akta seorang notaris harus dalam keadaan aktif artinya tidak sedang cuti jabatan atau diberhentikan sementara waktu.

Pasal 1 ayat (6) Permenkumham Nomor 17 Tahun 2018 tentang Pendaftaran Persekutuan Komanditer, Persekutuan Firma dan Persekutuan Perdata dalam hal ini Pemohon sebagai pendiri bersama-sama atau para sekutu yang akan mendaftarkan Persekutuan Komanditer, Persekutuan Firma dan Persekutuan Perdata yang memberikan kuasa kepada Notaris untuk mengajukan permohonan melalui SABU. Dalam hal notaris sebagai penerima kuasa dimana notaris bertugas menginterpretasikan apa yang diinginkan klien dalam bentuk akta, maka Notaris diharuskan memahami dan kompeten dalam melaksanakan Permenkumham Nomor 17 Tahun 2018 tentang Pendaftaran Persekutuan Komanditer, Persekutuan Firma dan Persekutuan Perdata tersebut, karena Notaris yang akan melakukan input data dari akta yang telah dibacakan dihadapan para pihak, yang tentunya penghadap sudah menyetujui dan memahami apa yang telah dibacakan dihadapannya. ${ }^{11}$

Menurut Merilee S. Grindle12, keberhasilan implementasi dipengaruhi oleh dua variabel besar, yakni isi kebijakan (content of policy) dan lingkungan implementasi (context of implementation). Variabel tersebut mencakup: sejauhmana kepentingan kelompok sasaran atau target group termuat dalam isi kebijakan, jenis manfaat yang diterima oleh target group, sejauhmana perubahan yang diinginkan dari sebuah kebijakan, apakah letak sebuah program sudah tepat, apakah sebuah kebijakan telah menyebutkan implementornya dengan rinci, dan apakah sebuah program didukung oleh sumberdaya yang memadai.

Dalam proses penerapan Permenkumham Nomor 17 Tahun 2018 terdapat beberapa kendala sebegai berikut:

a. Permasalahan di server atau perawatan dan menu didalam AHU online lebih ditingkatkan karena permasalahan masyarakat sangat kompleks dan belum masuk dalam sistem AHU tersebut.

b. Jaringan internet yang kurang memadai.

c. Kendala usia Notaris yang sulit beradaptasi dalam menerapkan Permenkumham Nomor 17 Tahun 2018.

Penyelesaian kendala- kendala tersebut adalah sebagai berikut:

a. Meningkatkan kualitas web AHU online, terutama dalam menu KBLI karena permasalahan yang dihadapi masyarakat sangat kompleks dan belum masuk dalam sistem AHU tersebut. ${ }^{13}$

b. Pemohon dapat mengajukan permohonan secara non-elektronik dalam hal permohonan pendaftaran pendirian, pendaftaran perubahan anggaran dasar, dan pembubaran Persekutuan Komanditer, Persekutuan Firma dan Persekutuan Perdata tidak dapat diajukan secara elektronik karena disebabkan oleh:

1) Notaris yang tempat kedudukannya belum tersedia jaringan internet;

2) SABU tidak berfungsi sebagaimana mestinya berdasarkan pengumuman resmi oleh Menkumham.

${ }^{11}$ Wawancara dengan Notaris Eti Ermawati Bertempat di Yogyakarta, pada 30 Maret 2020, pukul 14.00 Waktu Indonesia Bagian Barat

12 Subarsono, Analisis Kebijakan Publik: Konsep, Teori dan Aplikasi, Pustaka Pelajar, Yogyakarta, 2011, hlm. 93.

13 Wawancara dengan Notaris Ika Santy Yurista Bertempat di Yogyakarta, pada 18 September 2020, pukul 14.00 Waktu Indonesia Bagian Barat 
Permohonan-permohonan tersebut disampaikan secara tertulis dengan melampirkan:

a) dokumen pendukung; dan/atau

b) surat keterangan dari Kepala Kantor Telekomunikasi setempat yang menyatakan bahwa tempat kedudukan notaris yang bersangkutan belum terjangkau oleh fasilitas internet.

c. Meningkatkan Sumber Daya Masyarakat dengan mengadakan kegiatan sosialisasi dan pelatihan secara intens, dengan harapan agar seluruh pelaku usaha, instansi terkait dan para Notaris dapat memahami ketentuan Peraturan Menteri Hukum dan HAM tersebut. Dan kepada Notaris diharapkan mampu menerapkan Permenkumham Nomor 17 Tahun 2018 dengan maksimal dapat menyampaikan informasi mengenai pelaksanaan Peraturan Menteri Hukum dan HAM tersebut kapada masyarakat, sehingga masyarakat yang akan mendirikan Persekutuan Komanditer, Persekutuan Firma dan Persekutuan Perdata akan mendapat informasi yang tepat, lebih mudah dan lebih cepat.

\section{Penutup}

Setelah berlakunya Permenkumham Nomor 17 Tahun 2018, dalam melakukan pendaftaran pendirian Persekutuan Komanditer, Persekutuan Firma dan Persekutuan Perdata, pemohon harus terlebih dahulu melakukan pengajuan nama. Pengajuan tersebut ditujukan kepada Menkumham dengan mengisi format isian pengajuan nama melalui SABU. Permohonan perubahan anggaran dasar Persekutuan Komanditer, Persekutuan Firma dan Persekutuan Perdata diajukan oleh pemohon kepada Menkumham dengan mengisi format isian perubahan melalui SABU. Pembubaran Persekutuan Komanditer, Persekutuan Firma dan Persekutuan Perdata harus didaftarkan oleh pemohon kepada Menkumham dengan permohonan pendaftaran pembubaran melalui SABU. Dalam menerapkan Permenkumham Nomor 17 Tahun 2018 tersebut Notaris Kota Yogyakarta dapat melaksanakan dengan baik dan merasakan manfaat dengan berlakunya Permenkumham Nomor 17 Tahun 2018 tersebut. Adapun terkait dengan kendala dan penyelesaian dalam mengimplementasikan Permenkumham Nomor 17 Tahun 2018 antara lain, pertama, terkait permasalahan server, perlu adanya peningkatan serta perawatan server dan menu di dalam AHU online. Kemudian, terkait persoalan jaringan internet yang kurang memadai, penyelesaiannya dengan cara, Pemohon dapat mengajukan permohonan secara non-elektronik dalam hal permohonan pendaftaran pendirian, pendaftaran perubahan anggaran dasar, dan pembubaran Persekutuan Komanditer, Persekutuan Firma dan Persekutuan Perdata tidak dapat diajukan secara elektronik karena disebabkan oleh:

1) notaris yang tempat kedudukannya belum tersedia jaringan internet; atau

2) SABU tidak berfungsi sebagaimana mestinya berdasarkan pengumuman resmi oleh Menkumham.

Permohonan-permohonan tersebut disampaikan secara tertulis dengan melampirkan:

1) Dokumen pendukung; dan/atau

2) Surat keterangan dari Kepala Kantor Telekomunikasi setempat yang menyatakan bahwa tempat kedudukan notaris yang bersangkutan belum terjangkau oleh fasilitas internet. 
Hidayatus Sholehah. Implementasi Permenkumham No. 17 Tahun 2018... 173

Saran yang dapat diberikan oleh penulis adalah, Notaris diharapkan mampu mengikuti perkembangan zaman dengan meningkatkan sumber dara manusia yang ada, dan Kemenkumham diharapkan terus meningkatkan kualitas web dan terus memberikan penyuluhan, sosialisasi, serta pelatihan kepada Notaris sebagai pejabat umum yang memiliki kewenangan dalam melakukan pendaftaran CV, Firma, dan Persekutuan Perdata. Terkait kendala usia Notaris yang sulit beradaptasi dalam menerapkan Permenkumham Nomor 17 Tahun 2018, perlu adanya peningkatan sumber daya manusia melalui kegiatan sosialisasi dan pelatihan secara intens.

\section{Daftar Pustaka}

\section{Buku}

Habib, Adjie, Hukum Notaris Indonesia, Tafsir Tematik Terhadap UU No. 30 Tahun 2004 Tentang Jabatan Notaris, Refika Aditama, Bandung, 2008.

, Meneropong Khazanah Notaris dan PPAT Indonesia, Citra Aditya Bakti, Bandung, 2009.

Handri, Raharjo, Hukum Perusahaan, Pustaka Yustisia, Yogyakarta, 2009.

Hartanti, Sulihandari, dan Rifiani Nisya, Prinsip-Prinsip Dasar Profesi Notaris Berdasarkan Peraturan Perundang-Undangan Terbaru, Cetakan Pertama, Dunia Cerdas, Jakarta, 2013.

Subarsono, Analisis Kebijakan Publik: Konsep, Teori dan Aplikasi, Pustaka Pelajar, Yogyakarta, 2011.

\section{Peraturan Perundang-Undangan}

Peraturan Pemerintah Republik Indonesia Nomor 24 Tahun 2018 tentang Pelayanan Perizinan Berusaha Terintegrasi secara Elektronik

Undang- Undang Republik Indonesia Nomor 02 Tahun 2014 tentang Perubahan Atas Undang-Undang Nomor 30 Tahun 2004 tentang Jabatan Notaris

\section{Sumber Data Wawancara}

Wawancara dengan Notaris Eti Ermawati SH, Bertempat di Yogyakarta, pada 30 Maret 2020, pukul 14.00 Waktu Indonesia Bagian Barat

Wawancara dengan Notaris Ika Santy Yurista SH, M.Kn Bertempat di Yogyakarta, pada 18 September 2020, pukul 14.23 Waktu Indonesia Bagian Barat

Wawancara dengan Notaris Ika Santy Yurista SH, M.Kn Bertempat di Yogyakarta, pada 18 September 2020, pukul 14.00 Waktu Indonesia Bagian Barat

Wawancara dengan Notaris Muchammad Agus Hanafi. SH, Bertempat di Yogyakarta, pada 18 September 2020, pukul 14.23 Waktu Indonesia Bagian Barat 